\title{
Bomb Plans on the Internet: The Case for Constitutional Protection
}

\author{
Beau Breslin
}

This article addresses the central constitutional questions surrounding the debate over regulating speech that includes educational designs for bomb making. The aim of the article is to provide an additional, and in many ways, alternative justification for broad constitutional protection based on the core principles of free speech itself, and on the Court's historical treatment of differing subject matter. I argue that in addition to the more traditional First Amendment rules of overbreadth and vagueness, it is also important to consider the judiciary's evaluation of the content of speech itself when drawing conclusions about the constitutionality of legislation suppressing designs for the construction of violent material. Unlike unprotected speech, expression that includes designs for constructing explosives warrants constitutional protection because it belongs most closely to a category of speech — namely, scientific speech — that has traditionally been afforded protection.

\section{Introduction}

Conduct that amounts to 'advice' or 'persuasion' should be protected [by the First Amendment]; conduct that moves into the area of 'instructions' or 'preparations' should not.

$$
\text { - Thomas Emerson }(1970,75)
$$

There is danger that, if the Court does not temper its doctrinaire logic with a little practical wisdom, it will convert the constitutional Bill of Rights into a suicide pact. ${ }^{1}$

—Justice Robert Jackson

In 1979, the Federal District Court in the Western District of Wisconsin announced a decision that broke sharply with precedent in the area of First Amendment jurisprudence. United States v. Progressive, Inc. (1979) involved a successful attempt on the part of the United States to prevent The Progressive, a monthly magazine, from publishing technical details on hydrogen bomb construction in an article entitled "The H-Bomb Secret: How We Got It, Why We're Telling It."

At its most basic level, the case matched the principle of free expression against the continued viability of the state - the right of the individual against the safety of the polity itself. Consequently, the arguments on both sides reflect the seriousness of the debate. In defending the importance of free speech to a liberal democracy, The Progressive asserted that the designs

BEAU BRESLIN is an associate professor of government at Skidmore College.

The American Review of Politics, Vol. 25, Winter, 2004: 345-371

(C)2004 The American Review of Politics 
presented throughout the article did nothing more than add to the public's overall awareness of the problems associated with nuclear warfare, and that incomplete blueprints for the construction of H-Bombs would in no way threaten America's national security. Attorneys for the Government countered by insisting that details about the fabrication of hydrogen bombs, however incomplete, represented a "special" situation requiring swift action. It made no sense, the Government argued, to sit back and hope that the information provided by The Progressive would not get into the wrong hands. When forced to choose between the virtue of free expression and the guarantee of avoiding irreparable physical harm to the state, common sense dictated that the latter should prevail. Perhaps not surprisingly, the District Court agreed, adopting much of the Government's principal argument. The Judge explained that "a mistake in ruling against The Progressive will curtail defendant's First Amendment rights in a drastic and substantial fashion. [But a] mistake in ruling against the United States could pave the way for thermonuclear annihilation for us all" (United States v. Progressive, Inc. 1979, 17).

A quarter century later, the ruling in Progressive-which was later dismissed without opinion by the Federal Court of Appeals for the Seventh Circuit-remains relevant on a number of dimensions. Most obviously, the case represents a departure from First Amendment tradition in that the District Court considered, but then disregarded, the admonition by the Supreme Court that "any system of prior restraints of expression comes... bearing a heavy presumption against its constitutional validity" (Bantam Books v. Sullivan 1963, 70).

Yet the case is also important because it helps illuminate a debate-one that is becoming increasingly fierce-about the value of unfettered expression and the risks that often accompany a relatively free society. To what extent should we permit speech that may seriously threaten our national security? Few would suggest that the right to free expression should extend to those who can easily destroy all or part of the nation. But when the capability for massive destruction is not readily available to the everyday citizen (as was the case two decades ago and may still be the case now), or when the level of violence is defined as somehow less than the complete annihilation of the state (insert pipe bomb for hydrogen bomb), does that change our perspective on the speech itself? Should it?

This inquiry is made more complex when focusing directly on the speaker's motivations. There is a wide range of available information related to the manufacture of explosives, and not all of it is intended for use in a crime. Indeed, some bomb-making information has decidedly non-violent and non-criminal purposes. An important constitutional question emerges when one packages all bomb-making information under a single broad category and assumes that it leads inevitably to criminal activity: To what 
extent does the First Amendment protect disseminators of bomb-making information where there is no clear intent on the part of the speaker to aid in unlawful behavior?

The issue is further complicated when we reflect on the growing tendency to use the Internet as an instrument for the dissemination and distribution of noxious ideas. ${ }^{2}$ Now the world's most accessible source of information, the Internet has become the fashionable vehicle for many purveyors of bomb-making education. ${ }^{3}$ It may not be surprising that a portion of the information available on the Internet includes designs for the construction of weapons and other dangerous hardware. Perhaps more alarming is that a quick survey of available websites reveals that literally dozens - if not hundreds - of these sites include various guides for the manufacture and operation of bombs and other explosive devices. Manufacturing designs are easily accessible through many sources for a large variety of bombs, including pipe bombs, Mail Grenades, $\mathrm{CO} 2$ bombs, and weapons of mass destruction, but the Internet (unlike, say, a library) puts them literally at our fingertips. A Department of Justice Report (1997) recently noted that "law enforcement agencies believe that, because the availability of bomb-making information is becoming increasingly widespread, such published instructions will continue to play a significant role in aiding those intent upon committing future acts of terrorism and violence." ${ }^{4}$ What was once less accessible and more difficult to locate is now as easy to find as the latest stock quote or baseball score.

Finally, the inquiry is increasingly pertinent as we enter a period of unprecedented global uncertainty. Terrorism, it appears, will remain a part of the fabric of our lives, and thus an examination of the rules regarding the tools of the terrorist trade seems appropriate. Many remarked immediately following the events of September 11, 2001, that the suicide bombers were able to carry out their mission precisely because of the freedoms available to residents and visitors of the United States. Those who were responsible for the tragedy moved freely within America's borders; they spoke without restraint, and they lived anonymously. America's constitutional liberties supported their hatred. But if that is true, there may be no more suitable time than the present to reevaluate those basic freedoms. What better opportunity to reflect on the meaning of liberty than when its outlook is threatened? This article attempts to respond to that critical inquiry.

\section{The Focus and Organization of the Paper}

This article addresses the central constitutional questions surrounding the debate over regulating the type of speech that includes educational designs for bomb-making. The aim of the article is to provide an additional, 
and in many ways, alternative, justification for broad constitutional protection based on the core principles of free speech itself, and on the Court's historical treatment of differing subject matter. To date, much of the literature on the relationship between freedom of expression and speech advocating violence has neglected to consider some of the profound ideas that form the foundation of First Amendment jurisprudence (Doherty 1999; Ross 1999; Seigel 1999; White 1999; Phillips and Grattet 2000; Tsesis 2000; Marts 2003). This is troubling in part because these works tend to highlight the Court's favored tools for reviewing legislation that proscribes speechtools like overbreadth and vagueness - while downplaying more subtle ways to analyze regulation (Bernard 1999; Cole 1999; Miller 1999). I will argue that in addition to the more traditional First Amendment rules of overbreadth and vagueness, it is also important to consider the judiciary's evaluation of the content of speech itself when drawing conclusions about the constitutionality of legislation suppressing certain information. If one looks primarily at the judiciary's propensity to prioritize certain forms of speech, it becomes increasingly difficult to justify any regulation of the type of expression enjoined in the Progressive case.

The Court has regularly implied that there exists a hierarchy of speech that allows the judiciary to favor particular messages over others. Certain subjects, the Court has noted, are valued, and thus protected, more than others because they make more meaningful contributions to the progress and development of a liberal democratic regime. Not surprisingly, political speech has always rested at the top of this value hierarchy, with artistic and literary speech residing just slightly below. But scientific speech-speech that has genuine scientific merit-has also been resolutely protected by the Court. This of course begs the question: Should the distribution of plans for constructing bombs and similar destructive weapons - messages that are at the epicenter of the contemporary debate over Internet violence-receive constitutional protection under the First Amendment because other material containing genuine scientific value has instantly been afforded constitutional protection? Hydrogen and atom bombs represent landmarks in technological and scientific advancement, and one can easily find instructions on their construction. Does it naturally follow that to regulate such material would hinder scientific research; and that to distinguish hydrogen bombs from pipe bombs would be to enter too sticky a domain to attempt regulation?

The argument unfolds in three stages. First, I will describe congressional attempts to regulate bomb-making instructions and their availability to the public. More specifically, I will address recent congressional legislation surrounding the twin topics of violence and obscenity. Virtually all of the government's content-based regulatory attention over the past decade has been directed at the subjects of violence and obscenity because they are 
viewed as the most morally corrupting. A problem arises, however, when the legislature views the two subjects similarly. From a constitutional perspective, obscenity and violence are not treated identically. Unlike obscenity, speech that includes designs for constructing explosives warrants constitutional protection because it belongs most closely to a category of speechnamely, scientific speech - that has traditionally been afforded protection. Logically, therefore, the second section of the article is devoted to exploring the Court's hierarchical treatment of content and its consistent protection of scientific speech.

In the third and final segment of the article I will return to the specific legislation related to bomb-making instructions, considering it this time in light of the entire scope of First Amendment tradition. In the end I make two central arguments: that the type of speech targeted by congressional legislation should be defined as scientific speech, and that because it belongs to a category of speech that is highly respected by the judiciary, there should be little doubt that it will be placed under the protective umbrella of the First Amendment.

\section{Statutory Regulation of Instruments of Violence}

The inevitable result of the convergence of violence with the feeling of unease associated with a complicated and relatively new form of technology is a louder call for regulation. This country's lawmakers have been busy in the last few years exploring various methods of Internet regulation. Of the 30 content-based bills currently sponsored by one or more members of Congress, a significant portion single out children for protection against the type of noxious messages that pervade the Internet. The bulk of recent governmental regulations have attempted to prohibit transmitting, selling, or distributing sexually explicit and violent messages to minors. Proposed legislative enactments directed at graphic sexual and violent expression typically take two forms, with the least restrictive measures calling for some form of filtering while the more restrictive regulations attempting to criminalize, through the use of sanctions, the exploitation of viewers.

In 1995, amid growing concerns about domestic terrorism and the increasing availability to Americans of unregulated Internet sites with ties to hate groups or militias, Senator Dianne Feinstein (D-CA) introduced legislation placing limits specifically on bomb-making information. Her amendment to the Comprehensive Terrorism Prevention Act of 1995 (S. 735) read, in part:

It shall be unlawful for any person to teach or demonstrate the making of explosive materials, or to distribute by any means information pertaining to, in whole or in part, the manufacture of explosive materials, if the 
person intends or knows, that such explosive materials or information will be used for, or in furtherance of, an activity that constitutes a Federal criminal offense or a criminal purpose affecting interstate commerce.

The Feinstein amendment was the first of many subsequent attempts by Congress to prohibit bomb-making designs from appearing on Internet sites, and it remains the most successful. Originally dropped in conference, the Feinstein Amendment was then tacked on to the Defense Department authorization bills for both 1996 (S. 1026) and 1997 (S. 450), as well as the Antiterrorism and Effective Death Penalty Act of 1996 (S. 735). Each time, after being unanimously adopted by both the Judiciary Committee and the full Senate, it was removed in conference by House negotiators. In its place, Congress then directed the Justice Department to produce a report detailing the availability of bomb-making information and the threats posed by it.

The report supported Senator Feinstein's assertions that the increasingly widespread availability of bomb-making instructions, particularly through the Internet, posed a serious threat. The report noted that "such published instructions will continue to play a significant role in aiding those intent upon committing future acts of terrorism and violence" (1997). In addition, the report addressed free speech concerns, proposing an alternative wording for the amendment which the Justice Department felt was more likely to pass constitutional muster. Discovering that the Columbine killers had used directions obtained from the Internet to construct their bombs, Senator Feinstein was able to rally more public support for her amendment and win the backing of explosives manufacturers. Despite testimony from legal experts attacking its constitutionality, the Feinstein Amendment passed both the House and Senate, and was finally signed into law on August 17, 1999 , as a rider attached to an unrelated piece of legislation.

Like the Feinstein legislation, the Violent and Repeat Juvenile Offender Accountability and Rehabilitation Act of 1999 (S. 254) is a bill which would provide $\$ 1$ billion in block grants to combat juvenile crime as well as seek "to prevent children from accessing harmful materials on the Internet." It is, in fact, the most comprehensive bill ever introduced in Congress to restrict the role of the Internet in the development of the young mind. It carries stiff penalties for those who utilize the Internet as a tool for misbehavior, and it criminalizes a broad pool of expression. The House and Senate passed the legislation with bipartisan support in the spring of 1999 .

Specifically, the Violent and Repeat Juvenile Offender Accountability and Rehabilitation Act of 1999 combines both moderate (filtering devices) and more extreme forms of Internet regulation. On the one hand, the proposed legislation "encourages Internet service suppliers to provide free or low cost software to enable parents and administrators to block certain websites." The software Senator Hatch favors is the type that "filters" certain 
subjects from view, thus allowing parents to cut off access to minors of material deemed "inappropriate" or "offensive." On the other hand, however, the bill goes much further than simply filtering messages from the purview of the child: It actually criminalizes the act of posting plans that may eventually result in violence. The bill prohibits the "knowing transmission" over the Internet of any designs or plans that would result in the construction and subsequent use of firearms and other explosives. Put simply, "the bill," remarks Congressional Quarterly, "would establish penalties for teaching someone how to make or use a bomb over the Internet for use in a crime" (Ota 1999, 2040).

The Feinstein Amendment builds on these restrictions by actually criminalizing the act of posting blueprints or plans that may eventually result in violence. The dissemination of designs over the Internet for the construction of pipe bombs and other rudimentary explosives, as well as more destructive devices, falls under the general jurisdiction of the legislation. All designs, blueprints, descriptions and instructions for the creation of weapons and explosives are at risk. Thus the actual crime of using explosives would only be part of the state's general crackdown on violent activity. Any penalties that resulted from a violent act would also extend to the individual responsible for furnishing the plans for the particular weapon, even if that individual had only superficial knowledge of the violent act itself.

At each point in the policy-making process, Feinstein emphasized the need to focus on the issues of knowledge and intent. In fact, Feinstein was clear about the need to limit the reach of the legislation to those who have either the knowledge that their plans are being used for destructive purposes, or the intent to do harm. There is a distinction, she insisted, between sites devoted entirely to bomb-making instructions and those that have an alternative purpose. The aim of her amendment is to punish those whose specific goal is to engage in violence. Preparing an individual or group for criminal activity, she says, is distinguishable from speech that serves an educative function. Information provided by the military, explosives manufacturers, and encyclopedias, for example, might include designs for weapons such as bombs; but they remain protected by the First Amendment because the object of the publishers is not to aid and abet potential wrongdoers. In Noto $v$. United States (1961) and Brandenburg v. Ohio (1969) the Court echoed this position, insisting in each case that speech directed toward imminent lawless or violent action include a component of intent. Justice Harlan wrote in Noto: "the mere abstract teaching [of] the moral propriety or even moral necessity for a resort to force and violence, is not the same as preparing a group for violent action and steering it to such action" $(1961,298)$. Accordingly, Feinstein's legislation now carries the requirement of intent. ${ }^{6}$ 


\section{2 | Beau Breslin}

But intent is difficult to isolate. In fact, the Department of Justice report (1997) notes that the question of intent is one of degree: Is one criminally culpable when there is no demonstrable intent, but there still exists the possibility that information provided will be translated into criminal activity? Is the speaker responsible if she can "foresee" or has knowledge that the consequences of her speech might result in potential destruction? We might not quibble with Feinstein's legislation if we could be sure that law enforcement agents are able to distinguish between those intending to commit criminal acts from those who have other plans for their websites. But even law enforcement cannot guarantee such results. As such, the responsibility for determining intent will likely fall on the judiciary, where judges and juries will have to consider the issue on a case-by-case basis. There is, in fact, no jurisprudential way of creating a bright line in this area of inquiry.

The legislative attack on certain Internet information may be effective politically (it signals to constituents that representatives are serious about violence and the moral corruption of minors), but it is puzzling from a constitutional standpoint. Reflecting on the efficacy of the separate types of regulation, it must be conceded that only one strategy actually protects children without significant, and perhaps unacceptable, damage to the First Amendment. Filtering devices are indeed successful in isolating subjects from the purview of selected constituencies - students, children at home, etc.-without preventing all from accessing the sites. It is, however, the sanctions associated with the Feinstein and Hatch legislation that raise serious questions about their impact on free speech. Problematic is the fact that both pieces of legislation mandate that the author of a specific website-not just the individual who uses the information for violent ends - must also be punished. The author of the website becomes a criminal by virtue of having "contributed" to the violence by including designs for destructive weapons on the website; he is an accomplice to the crime because of the message alone. Congressional legislation seeks to protect juveniles and others from the devastating impact a bombing attack could have, yet the bills criminalize pure speech - speech that may be distasteful, but that is nonviolent in and of itself.

The success of legislation like the Feinstein Amendment sets up a renewed constitutional battle between the twin forces of free expression and state security. And yet Congress's recent attempts to regulate the Internet may actually result in speech restrictions on a far wider scale than those imposed upon The Progressive. Similar to the government's attempt to prohibit a member of the print media, with limited circulation, from publishing blueprints of the H-Bomb because of their potential for destruction, the Feinstein Amendment and the Hatch legislation have the potential to severely restrict bomb-making designs-both simple and complex-from more 
contemporary and technologically advanced sources. That reality, combined with the realization that a much wider audience accesses the Internet, suggests that at a minimum such restrictions warrant careful constitutional examination.

\section{The Constitutional Argument}

\section{Chilling Effect, Overbreadth, and Vagueness}

The typical, and initial, judicial response to legislation that is not tightly written-legislation resembling the Feinstein and Hatch bills - is that potential speakers will likely be deterred from speaking because of fear of punishment. Statutes that regulate expression are occasionally flawed in that they are drawn too broadly or with unacceptably vague language, the result of which is that individual speakers may not be sure about the specific coverage of the statute. On occasions such as these, the speaker may be confused as to whether her words fall under the regulatory parameters of the legislation. Human nature suggests that in those situations most of us would prefer to err on the side of caution; it is better not to speak than to risk punishment.

The idea that the tidiness of the legislation can impact the courage of the speaker-an idea informally known as the "chilling effect"-has spawned the doctrines of overbreadth and vagueness, two of the most prominent means of free speech analysis employed by the judiciary (Amsterdam 1960; Note 1969; Redish 1983; Jeffries 1985; Fallon 1991). The overbreadth doctrine refers to legislation that "sweeps too broadly" in its attempt to criminalize unprotected speech and thus interferes with constitutionally safeguarded speech. Like overbreadth, vagueness also refers to the tightness and narrowness of a written piece of legislation. Indeed, a law defined as vague would also cause a chilling effect in that the speaker is likely to be frightened out of the marketplace. Again, human nature suggests that if we are unsure of the scope of a law, we are more inclined to remain silent. Yet the vagueness doctrine differs from overbreadth in important ways. As the word indicates, vague legislation is unconstitutionally unclear; it is written in a manner that makes it difficult to determine specifically what expression is outlawed.

Overbreadth and vagueness are certainly critical components of many First Amendment cases, including those related to regulating bomb-making designs. They may in fact govern any number of future cases involving bomb-making education both on the World Wide Web and in other venues. Nevertheless, they are but a fraction of the overall story. To capture a more nuanced understanding of the probability that regulations suppressing bomb- 
making instructions will successfully maneuver the pathways of constitutional scrutiny requires that we look more carefully at the broader picture of First Amendment adjudication. Underneath the surface of all free speech cases is the judiciary's implicit evaluation of the speaker's content. The Court's hierarchical ordering of subject matter is not an explicit component of the formal rules of constitutional inquiry, yet it has a significant impact on the outcome of individual cases. Where a particular subject falls along the hierarchy of speech will help determine the level of scrutiny imposed by the Court, and that level of scrutiny will no doubt determine the constitutionality of any given piece of legislation. To be sure, most governmental regulations of speech trigger strict scrutiny, but certainly not all. ${ }^{7}$ As such, it seems appropriate to consider the Court's hierarchy of speech as a further way to analyze legislation interfering with certain types of expression.

\section{The Hierarchical Nature of Free Speech}

In trying to explicate the meaning of the First Amendment, the federal judiciary has long insisted that the Free Speech provision holds a privileged or special place in relation to the other constitutional freedoms. It holds this privileged position because freedom of speech is arguably the right on which all other rights are affirmed; it is the right that rests at the cornerstone of the American political experiment.

Yet despite this privileged position, an important debate on the comprehensiveness of the First Amendment endures. This debate is concerned less with the technical faults of legislation - to which the adjudicative rules of overbreadth and vagueness belong - than with the substantive breadth of the free speech provision itself. Which specific subjects should be safeguarded and which should fall outside of First Amendment protection? Some jurists have argued that the First Amendment is so broad in its protection of speech that Congress can in fact pass no law abridging the freedom; that no subject is left unprotected by the First Amendment. Justice Black, for example, espoused his famous absolutist position in Konigsberg v. State Bar of California (1961) when insisting that he did "not subscribe to the balancing doctrine that permits constitutionally protected rights to be 'balanced' away when a majority of the Court thinks that a state might have interest sufficient to justify abridgement of those freedoms" (Konigsberg v. State Bar of California 1961, 61).

Nevertheless, some have insisted that the First Amendment, like most other rights, can and should at times be surrendered to the common good. Consider Justice Harlan's statement in Konigsberg rejecting the principle of absolutism: "Throughout its history this Court has consistently recognized [that] constitutionally protected freedom of speech is narrower than an 
unlimited license to talk.... Whenever constitutional protections are asserted against the exercise of valid governmental powers a reconciliation must be effected, and that perforce requires an appropriate weighing of the respective interests involved" (Konigsberg v. State Bar of California 1961, 49-51). These competing statements undercut the claim that the debate over the comprehensiveness of First Amendment protection has been resolved. The modern history of First Amendment adjudication clearly shows that the Supreme Court is predisposed to strenuous protection of First Amendment freedoms. Yet the Court has also concluded that some utterances are decidedly unworthy of constitutional protection. There exists, in fact, a realm of ideas so noxious and so antithetical to the ideals from which the First Amendment draws its meaning that they do not enjoy judicial protection at all. Accordingly, such expression has been categorically removed from the realm of First Amendment refuge based on its subject matter alone. It falls under the imaginary line by which the Court separates speech that warrants the strictest First Amendment security from expression that offers such a minimal contribution to the democratic experience that any rational or reasonable state interest will suppress it.

The case in which this point is most clearly elucidated is Chaplinsky $v$. State of New Hampshire (1942). In Chaplinsky, the Court concluded that the appellant's violent speech had such little redeeming value that it should be categorized outside of First Amendment protection. Chaplinsky ushered in a new era of constitutional adjudication resulting in several types of speech determined to be outside the realm of constitutional protection. Those categories of speech included "the lewd and obscene," "the profane," and "the libelous," as well as "the type of insulting or fighting words" that characterized Chaplinsky's particular message.

Stepping back from our analysis of individual cases, an image of free speech case law thus emerges which includes the Court's practice of evaluating substantive content. When examining First Amendment adjudication, one finds the Court has recognized a clear hierarchy based on the specific content of the speech itself; some utterances warrant more protection than others because of their more critical contribution to the polity. At the top of this hierarchy of protected speech is political speech, or speech directed toward "public concerns." Such expression occupies the preferred position on the hierarchy because it contributes, more so than any other type, to the development of our democratic regime. In a representative democracy political speech anchors the foundation from which all governmental action derives its authority. Active participation in government requires that the citizens of the polity be capable of articulating their dissatisfactions, all in the name of pursuing public goals. In fact, the language of the First Amendment even implies this essential function of speech. In considering the 
importance of political speech in a liberal democracy, one must remember that the people retain the right "to petition the Government for a redress of grievances."

In New York Times Co. v. Sullivan (1964), Justice Brennan asserted the importance of political speech by insisting that "a profound national commitment to the principle that debate on public issues should be uninhibited, robust, wide-open, and that it may well include vehement, caustic, and sometimes unpleasantly sharp attacks on government and public officials" (New York Times Co. v. Sullivan 1964, 270). And yet there is perhaps no more decisive statement of the value the Supreme Court places on political expression, however, than the one in the 1985 case of Dun \& Bradstreet, Inc. v. Greenmoss Builders, Inc., a case that significantly and importantly narrowed the Court's earlier rulings in the area of libel. Writing for the plurality, Justice Powell distinguished speech "on matters of purely private concern" from speech that related to "public concerns," concluding that the former lies "farther from the core of the First Amendment" (Dun \& Bradstreet, Inc. v. Greenmoss Builders, Inc. 1985, 758-760). Powell insisted that "not all speech is of equal First Amendment importance." "Speech on public issues," in fact, "occupies the "highest rung of the hierarchy of First Amendment values,' and is entitled to special protection" (Dun \& Bradstreet, Inc. v. Greenmoss Builders, Inc. 1985).

At the opposite end of the hierarchical ordering of protected speech lies pornography, the lowest valued subject on the continuum. For a time, the Supreme Court struggled with the problem of making a distinction between obscene material and material defined simply as pornographic. Initially, the Court was forced to determine whether to qualify pornography as low value speech or whether to categorize it outside of First Amendment protection altogether. The Court, however, has concluded that it is in fact protected speech. The Court's unanimous opinion in Sable Communications Inc. v. FCC (1989) directly commented on the constitutional distinction that must be made between obscene speech and speech that is merely sexually offensive or indecent. The Sable decision built upon an earlier decision in which the Court argued that "where obscenity is not involved, we have consistently held that the fact protected speech may be offensive to some does not justify its suppression" (Carey v. Populations Services International 1977, 701).

Though the Court has specifically acknowledged that pornography occupies the protected category of low value speech, it has also regularly supported governmental restrictions by balancing the importance of the speech with the interest in protecting individuals from the moral corruption that often accompanies pornographic messages. Frederick Schauer has commented that "restrictions on sexual expression will be permitted [by the Court] so long as those restrictions do not have the effect of a de facto 
prohibition on dissemination" (Schauer 1981). Further, Justice Stevens has even gone so far as to suggest that pornographic utterances have little import in our long and proud tradition of protecting free expression. He admitted that "few of us would march our sons and daughters off to war to preserve the citizen's right to see 'Specified Sexual Activities' exhibited in the theaters of our choice." 8

The Court's variable treatment of pornography and obscenity permits us to conclude that between the two sexually explicit categories lies the imaginary line separating protected speech from unprotected speech. Indeed, the division represents an important position on the Court's hierarchical ladder in that it marks the exact point at which certain speech will be protected. Above the line rests pornographic expression which the Court has determined to be valuable enough to warrant at least minimal constitutional protection. Below the line resides obscenity that may share some of the general characteristics of pornography but is so graphic and offensive in its portrayal of sex that it does not rise to the level of protection. Juxtaposed, the subjects of obscenity and pornography help illuminate more fully the Court's varied attitude with regard to differing content.

Slightly above pornography lies expression related to commerce. Commercial speech had not been acknowledged to fall within First Amendment protection until 1976 when, in Virginia Pharmacy Board v. Virginia Citizens Consumer Council, the Court finally raised commercial expression above the imaginary line separating protected from unprotected speech. Yet, in the Virginia Pharmacy Board case, it was also determined that such expression could easily be regulated, and that it was to be defined as "lower value speech." The question Justice Blackmun posed in his majority opinion was whether an utterance which does "no more than propose a commercial transaction is so removed from any 'exposition of ideas' and from 'truth, science, morality, and arts in general' . . that it lacks all protection" (Virginia Pharmacy Board v. Virginia Citizens Consumer Council 1976, 762). Concluding that commercial speech is not so far removed, Blackmun argued that in some situations it may in fact prove beneficial to society. But, he continued, such speech also cannot be said to contribute mightily to the marketplace of ideas. Commercial speech would never be afforded the same protection as "core speech," argued Blackmun. In Virginia Pharmacy Board the Court settled on a lower level of scrutiny for commercial expression.

Just beneath political speech on the value hierarchy-but just above commercial expression - is speech that is determined to be of literary, artistic, or scientific merit. One purpose of free expression is to produce an informed citizenry that can be confident in the practice of self-governance. To facilitate representative government, the polity must be capable of making credible, rational, and well-founded decisions on all issues of public 
importance. Hence the need for a broad marketplace of ideas. It has been suggested by the Court that literature, art, and science facilitate the requisite acquisition of knowledge our governmental system requires. In fact, it has been argued that political speech cannot truly exist independent of literature, art, and science. Alexander Meiklejohn has noted that "art, literature, philosophy and the sciences should indeed be included in the First Amendment, as they help 'voters acquire the intelligence, integrity, sensitivity, and generous devotion to the general welfare that, in theory, casting a ballot is assumed to express"' (Meiklejohn 1948). Artistic, literary and scientific speech, therefore, serve two ends: First, they contribute to the quality of humanness, the idea that we are humans precisely because of our ability to communicate, reason, and recognize the aesthetic value of our environment. Secondly, literary, artistic, and scientific expression also contribute to the principle of self-rule. Indeed, we cannot conceive of the common good without also recognizing the role that art, literature, and science play in achieving that promise.

The placement of literary, artistic, and scientific expression on the speech hierarchy can best be elucidated by the cases dealing with obscenity. In Miller v. California (1973), the Court articulated the test to determine whether speech can be classified as obscene. The third prong of this test is of particular importance to our inquiry, as it states that when deciding levels of First Amendment protection, one must consider "whether the work, taken as a whole, lacks serious literary, artistic, political, or scientific value" (Miller v. California 1973, 24). Messages that are defined as obscene certainly lack the requisite value, but the implication of the Miller test is that these four varieties of speech are models by which all speech should aspire precisely because these forms of speech are of value to society. They in fact occupy the highest rungs on the ladder.

Furthermore, one can also look to FCC v. Pacifica Foundation (1978) where the court once again emphasized the importance of speech possessing "literary, political, or scientific value" $(1978,746)$. George Carlin's monologue in which he recited the "seven dirty words" was viewed by the Court as offensive, but not (by itself) completely devoid of value. The words themselves, Justice Stevens argued, must be viewed within the context of their circumstances, and these words occupy a low, but constitutionally protected, position on the value hierarchy. What makes the government able to restrict them in this particular instance, Stevens says, is the fact that they were "uniquely accessible to children" because they were broadcast over the radio (FCC v. Pacifica Foundation 1978, 749).

Finally, one can draw a similar conclusion about the position of literary, artistic, and scientific value by again reviewing the case of Virginia Pharmacy Board v. Virginia Citizens Consumer Council (1976). Here, the 
court (while contemplating the depth of constitutional protection for commercial speech), had to consider whether such speech was so far removed from "truth, science, morality, and art" to merit First Amendment protection. The Virginia Pharmacy Board case affirms the importance that these categories of speech have earned in American jurisprudence.

Specifically, the value of literature and art in our great constitutional experiment cannot be denied. In Hurley v. Irish-American Gay, Lesbian and Bisexual Group of Boston (1995), the Court asserted that examples of painting, music, and poetry are unquestionably shielded by the First Amendment. Also, in Kaplan v. California (1973), the Court insisted that pictures, films, painting, drawings, and engravings enjoy a high degree of constitutional protection. The expressive nature of art and literature allow them to enjoy the full protection of the First Amendment precisely because our cultural life is completely and utterly dependent upon them.

Scientific expression has also been afforded a great degree of constitutional protection. Justice Frankfurter's concurring opinion in Sweezy v. New Hampshire (1957) suggests that scientific expression is of paramount importance and that the "freedom to reason and [the] freedom for disputation on the basis of observation and experiment are the necessary conditions for the advancement of scientific knowledge" $(1957,261)$. Frankfurter continues in Sweezy by insisting that "[p]rogress in the natural sciences is not remotely confined to the findings made in the laboratory. . . . Political power [therefore] must abstain from intrusion into this activity of freedom, pursued in the interest of wise government and the people's well-being, except for reasons that are exigent and obviously compelling" $(1957,262)$. Indeed, the implication of these and other statements is that scientific advancement cannot occur in a vacuum - there must be a free exchange of scientific ideas to promote innovation. But the equally obvious constitutional lesson that emerges from the Sweezy statement is that if the government seeks to regulate scientific expression, and thus satisfy the Court's rigorous First Amendment scrutiny, it must identify a compelling interest and means that are narrowly tailored - traditionally a difficult task for any state attorney. ${ }^{9}$

The practice of identifying particular utterances that warrant First Amendment protection raises important implications about the Court's attitude towards speech in general. Some messages undoubtedly carry greater judicial protection than others, while some enjoy no protection at all. The history of First Amendment adjudication reveals that the Supreme Court has engaged in a pattern of variable treatment for different types of protected (and unprotected) expression. Indeed, the Court's hierarchy of speech can be a useful guide when evaluating the constitutional legitimacy of legislation directed at specific subject matter. 


\section{The Constitutionality of Bomb-Making Instructions}

The Court's variable treatment of speech provides an invaluable means by which students of American constitutional law can analyze the legitimacy of proposals to regulate violent speech. Specifically, I want to suggest that we look beyond the traditional principles of vagueness and overbreadthtools that are admittedly quite powerful when reviewing the legality of laws restricting speech - to other components of the Court's treatment of speech when considering whether the judiciary will uphold congressional and state action that seeks to minimize access to certain violent language.

The Feinstein Amendment, the 1999 Violent and Repeat Juvenile Offender Accountability and Rehabilitation Act, and similar legislation directed at violent messages may also suffer from certain constitutional maladies. That of course is the duty of the judiciary to determine. But any inquiry surrounding these bills' major tenets must also acknowledge the fact that they restrict an area of speech traditionally located quite high on the value hierarchy. Scientific speech has always been afforded persistent First Amendment protection from the judiciary. These measures will suppress expression that involves designs or plans for constructing explosive devices, and that presumably includes messages that have genuine scientific merit. The main target of the legislation-pipe bombs - are admittedly primitive examples of explosives and thus cannot be regarded as contributing significantly to the advancement of science. But that misses the jurisprudential point. Insofar as the atom bomb, the hydrogen bomb, and the innovations that surrounded the Manhattan Project and its progeny have been lauded as serious scientific achievements, and they too are criminalized by recent legislation, then we are forced to make a distinction between instruments that significantly advance science and ones that do so on a less evident scale - a distinction that the judiciary is unlikely to make. In fact, because of their comparative devastating effect, one can logically argue that the more sophisticated the bomb, the more its ingredients ought to be monitored and regulated. And yet legislators regularly praise the scientific advances that have accompanied development in the area of nuclear weaponry. No legislator will soon praise the scientific achievements associated with the pipe bomb; but neither will they likely deny that primitive bombs, like sophisticated bombs, still fall under the broad category of weapons.

All bombs are admittedly devastating, but many are also quite impressive from a purely scientific point of view. They represent landmarks in technological advancement - from chemistry to physics to engineering — and one can readily locate instructions for their construction from various sources, including the Internet. The argument can be made that regulating such material could pose an obstacle to further scientific research, research 
that has little to do with the destructive capacity of the bombs themselves. Research into explosives that by our current standards would be defined as rudimentary - the invention of dynamite by Alfred Nobel, for examplehave paved the way for the creation of legitimately sophisticated weaponry that has helped the western world defeat the fascist, communist, and genocidal regimes of the past century. ${ }^{10}$

Yet military successes are not the extent of the relationship between science and violence. Particular achievements in the area of chemical reactions, engineering structures, triggering mechanisms, and so on, owe at least part of their effectiveness to their association with earlier advancements in the science of ballistics. Future developments in these areas might conceivably suffer because of regulations on distributing information related to weaponry. It might be useful to recall Frankfurter's admonition in Sweezy $v$. New Hampshire that "[p]rogress in the natural sciences is not remotely confined to findings made in the laboratory. Insights into the mysteries of nature are born of hypotheses and speculation. ... For society's good-if understanding be an essential need of society-inquiries into these problems, speculations about them, stimulation in others of reflection upon them, must be left as unfettered as possible" (1957, 261-62).

Indeed, advancements in power capabilities or conservation are also deeply intertwined with research performed on explosives. Ensuring that nuclear power plants are safer and more efficient, for example, demands that we think again and again about the same technology that supports the development of atomic weaponry. ${ }^{11}$ Like all types of inquiry, scientific research requires the ability to explore hypotheses and examine data in an environment that is largely free of sanctions, and that includes locating and discovering information from various Internet resources, as well as more traditional avenues.

Another dimension in this debate involves the legislature's habit of packaging certain sexually explicit material with violent material and then outlawing it wholesale. Even leading First Amendment scholars like Kevin Saunders (1996), who insists "violence is at least as obscene as sex," admit that America's courts currently view the subjects differently. ${ }^{12}$ In the judiciary's mind, speech defined as obscene is qualitatively different than speech defined as violent, and yet legislators often view them as related. In fact, most legislation regulating messages intended for children conjoin obscene/ indecent sexual language with violent material as if they are equally offensive to the state and to the listener. The Children's Defense Act of 1999 (H.R. 2036) is an example of this broad type of legislation. The bill sets penalties for "knowingly soliciting, selling, loaning, or exhibiting to a minor, in interstate or foreign commerce, a picture, photograph, drawing, sculpture, video game, motion picture film, or similar visual representation or image, 
book, pamphlet, magazine, printed matter, or sound recording containing explicit sexual or violent material or detailed verbal descriptions or narrative accounts of explicit sexual or violent material" (emphasis added). In the eyes of the judiciary, however, obscene and violent materials are not at all equivalent. Obscenity remains outside the protective borders of the First Amendment regardless of the listener's particular age. Such utterances are said to have little or no "redeeming social importance." They contribute in no tenable way to the ideas that form the foundation of the American political experiment or to the more general pursuit of truth. Accordingly, the judiciary permits the state to engage in a form of content-based restriction when it outlaws obscenity.

In contrast, messages defined as violent have not been viewed by the recent Court as altogether devoid of importance. In fact, the opposite may be more accurate. The act of violence-reprehensible as it is - is an essential part of our collective history. It has helped define who we are as a nation from the moment of independence to the present, and thus depictions and narratives about violence typically find protection in America's courtrooms. Violent resistance is a component of our social fabric; hence speech that tells the story of violence in this country is generally regarded as contributing to our overall civic education. ${ }^{13}$ The judiciary has concluded that these messages have value, while obscene material does not. ${ }^{14}$

As early as 1948, the Court first considered a case that involved the government's regulation of both sexual and violent speech. Winters $v$. New York (1948) centered around a First Amendment challenge to a state law that made it illegal to distribute "any book, pamphlet, magazine, newspaper or other printed paper devoted to the publication, and principally made up of criminal news, police reports, or accounts of criminal deeds, or pictures, or stories of deeds of bloodshed, lust or crime." The Court concluded that such a law could not withstand constitutional scrutiny because it required the individual to "guess" at the meaning of the punishable concepts (Winters $v$. New York 1948, 518). Perfectly constitutional literature like "detective stories, treatises on crime, reports of battle carnage, etc." would have been subject to the New York criminal code, the Court argued (Winters v. New York 1948, 512).

What is perhaps more telling about Winters, however, is the fact that the New York State legislature crafted the overbroad statute around the obscenity laws of the period. Much of the language of section 1141 of the New York Penal Code was taken directly from the state obscenity statutes; in fact, there is a component of the law that prohibits distributing "lustful" material. The aim of both the New York State legislation and the obscenity statutes was the same: to prevent the type of immoral behavior that inevitably leads to lawlessness. The Court, though, saw the two subjects as impor- 
tantly distinct. Justice Reed argued that the law did not "limit punishment to the [sexually] indecent and obscene" but also included utterances that belong to an entirely different category of speech, a category that has long been afforded protection by the First Amendment. He intimated that depictions of battles, for example, including presumably those battles that America celebrates as pivotal to its collective historical development, could not in any reasonable way be classified together with graphic sexual speech and discarded as unimportant. To do so would be to draw definitional lines far too broadly.

Admittedly, few are likely to confuse the violent, though noble, story of our revolutionary roots with an Internet site that describes plans for constructing pipe bombs. However, as Winters addressed, insofar as violence constitutes a specific subject matter distinct from obscenity, it becomes problematic not only for the legislature to package them together, but also for the judiciary to draw distinctions within each category between valued and unvalued speech, between important and unimportant messages. The legacy of neutrality that pervades First Amendment adjudication is one that suggests the Court is reluctant to declare certain utterances within a single category valuable while simultaneously condemning others. This holds true even if the courts are willing to draw distinctions between categories. Clearly the generalist nature of the institution influences the judiciary's approach to different categories of speech. The institution can recognize distinctions between categories, and even treat differing categories in different ways, but within individual categories the Court is reluctant to make value determinations.

A different perspective may help. It is important to remember that in all but one area of First Amendment adjudication (sexually explicit speech being the anomaly) the Court has refused to engage in line drawing within distinct categories of speech. The Court regularly avoids making determinations about what constitutes valuable speech within a particular category and what ought to be defined as valueless within that same category. A crude political cartoon, for example, is afforded the same constitutional protection as an important political treatise simply by virtue of its membership in the category of political speech. ${ }^{15}$ Artistic work defined by experts as masterful will not receive additional First Amendment protection because it is more aesthetically pleasing than lesser-known works. Mediocre or bad art is guaranteed the same level of constitutional protection as critically acclaimed art. What is more, the same principle of neutrality also extends to differences in the substantiality of the speaker. An unknown speaker can expect the same constitutional treatment as would a representative of the New York Times or the Washington Post, provided that the unknown speaker's words fall under a protected category of speech. 
This general form of restraint is attributable at least in part to the nature of an independent judiciary. The judiciary is almost always cognizant of its position as largely separate from the influence of politics. Its members (at least in the federal judiciary) are rewarded with life tenure and fixed salaries in exchange for the promise of independent and objective judgment. They are expected to remain dispassionate when ruling on the specifics of each case. True, judges often do not act objectively. But the reality of judicial bias does not undermine the claim that the institution was designed to maximize the possibility of impartiality (Federalist 78). Indeed, there is little doubt that the pressure on judges to remain unbiased is intense. Moreover, the independent nature of the judiciary also contributes to the belief that judges are generalists unequipped to make expert determinations about the quality of one message or the wisdom of another policy. Thus when it comes to evaluating speech that involves judgments on the merits of the message, the judiciary more often than not steers away from such specialist determinations.

The one area of First Amendment adjudication that does not exactly adhere to the rule of neutrality involves sexually explicit speech. The judiciary has, in fact, drawn a line separating protected sexual speech from unprotected sexual speech. Obscene utterances are not covered by the First Amendment, whereas pornographic speech - sexual speech that is defined as simply offensive or indecent - is usually protected even when regulated. In light of this break with constitutional tradition, it seems important to reconcile the inconsistency; for to draw a distinction in the area of sexually explicit speech is to allow the possibility of drawing a similar distinction between valuable science and science that does not contribute in meaningful ways to the marketplace of ideas.

Such an inconsistency can be explained more easily by looking closely at the judiciary's philosophy on viewpoint discrimination. Judge Easterbrook of the Seventh Circuit Court of Appeals captured well the subtle distinction between traditional content-based regulations and more narrow restrictions based upon viewpoint. In American Booksellers Association, Inc. v. Hudnut (1985) the majority of the Seventh Circuit invalidated an Indianapolis ordinance that sought to suppress pornography because its central message included the subordination of women. Easterbrook's majority opinion considered the issue of whether pornography should be defined as "low value speech." He concluded that the answer to that question must be no, but in the process, he made a number of important comments about the judiciary's subtle approach to categorization.

"The Court," he insisted, "balances the value of speech against the cost of its restriction, but it does this by category of speech and not by the content of particular works" (American Booksellers Association, Inc. v. Hudnut 
1985, 332-33). In other words, the Court permits different degrees of regulation at the category level - political speech, literary speech, sexually explicit speech, and so on-but will not tolerate different treatment at the subcategory level. Easterbrook's claim includes two critical components: First, he argues that when the Court categorizes speech it does so without regard to specific messages, and, second, he suggests that the Court is likely to be far more skeptical of legislation that discriminates against particular viewpoints within separate categories. A city ordinance that defines pornography as the "graphic sexual subordination of women" must be subject to the highest judicial scrutiny because it isolates a particular and very narrowly defined message for punishment. Pornography that treats women as equals or superior to men may be more disturbing in its graphic detail, but it remains unaffected by legislation that only prohibits messages related to the inferiority of women. The Indianapolis ordinance discriminates against a specific viewpoint, Easterbrook concluded, by creating a sub-category of unprotected speech within the larger category of protected speech.

The judiciary is far more inclined to protect speech whenever possible and thus Easterbrook's focus on acceptable speech related to sexual conduct rather than speech that is not protected is consistent with the history of free speech adjudication. He appears to be echoing an implicit argument made often by the federal judiciary that, whenever possible, speech should be protected. Easterbrook correctly interprets the difference between pornography and obscenity not as an attempt to dislodge a particular category from constitutional protection, but rather as an attempt to maximize as much as possible the speech that falls within the parameters of the First Amendment. Indeed, his skepticism regarding governmental regulation of speech is well founded, and it can apply with equal force to other areas. Creating a subcategory of scientific speech that prohibits the dissemination of plans aimed only at rudimentary forms of explosives would be analogous to restrictions imposed on pornography. Because scientific speech is afforded constitutional protection, claiming that "bad" science falls outside the protective area of First Amendment jurisprudence would be tantamount to viewpoint discrimination. All indicators seem to suggest that the Court will not tolerate such line drawing. ${ }^{16}$

Legislation that prohibits disseminating plans for constructing pipe bombs and similar weapons also cannot be considered neutral as to viewpoint. There is little doubt that governmental restrictions on violent websites create a sub-category of unprotected speech within the larger realm of protected scientific expression. The distribution of other scientific blueprints is not proscribed by any legislation, and neither are designs for closely related hardware. A website devoted broadly to timing mechanisms, for example, would not be criminalized by these bills even though timing mechanisms are 
arguably the most crucial element in constructing most bombs. Furthermore, detailed descriptions of warfare or narratives describing the events surrounding each discovery in the area of ballistics may be more critical to creating crude weaponry than are more germane websites which are difficult to locate and even more difficult to decipher. Yet these works are not similarly regulated by any congressional or state action. They are awarded their full share of First Amendment protection not only because they represent important contributions to the marketplace of ideas but also because they belong to a category of speech that has long been safeguarded by the Court.

Scientific expression occupies a very lofty position on the First Amendment hierarchy, a position directly below that reserved for political speech. That much is certain. What is also clear from the historical overlap of scientific advances and advances in weaponry is that proposals to regulate or restrict messages over the Internet based on their contribution to America's pattern of violence may interfere with the development of scientific research. Pipe bombs may not represent the kind of accomplishments reserved for greater scientific achievements, but they are part of a larger inquiry into the nature of science itself. As such, the judiciary is not likely to treat them in a dramatically different way.

\section{Conclusion}

It is always dangerous to speculate on the reactions of judges to difficult cases. Supreme Court justices in particular are often reluctant to introduce bright line tests, especially in the area of free speech. Much of the Court's First Amendment jurisprudence has been shaped by a case-by-case approach. And yet one cannot help but be skeptical of the constitutionality of legislation that regulates designs for bomb-making. The Court's long history of suspicion when it comes to content-based regulation combined with its insistence that the Internet represents a different type of communicative tool - one that requires "affirmative steps" to retrieve information - suggests that the inevitable judicial battle over the constitutionality of any related law will be fierce. Senator Feinstein and those who support her amendment probably view legislation that attempts to suppress violent speech as representing a subtly different type of prohibition than that which doomed the Communications Decency Act (Reno v. American Civil Liberties Union 1997). Perhaps they are ostensibly correct in suggesting that prohibiting speech that leads directly to violence is somehow more defensible than speech that "appeals to the prurient interests" of youths. Violence, after all, is by its very nature more "destructive" than that which corrupts a single individual's moral constitution. Perhaps also the members of Congress who support these restrictions on Internet violence are relying on the sociological 
impulse of past Courts, and are hoping that the present Court will recognize the need for preemptive action to prevent future acts of terrorism and violence. It is even conceivable that members of Congress who have sponsored these pieces of legislation care little about the Court's position and are instead advocating the restriction on the basis of political expediency.

From a legal perspective, both political and judicial opponents of the Feinstein Amendment need only emphasize the vague and overbroad qualities of this particular legislation to conclude that its central tenets infringe too much into the area of protected speech. It is purely a content restriction, opponents will suggest, and because content-based laws are presumptively unconstitutional, it is highly unlikely that the Court will sustain this law. Statutes that criminalize particular subject matters that in other forms are protected by the First Amendment have a strong tendency to preclude otherwise constitutionally protected speech. Laws, in other words, causing a chilling effect rarely survive the Court's careful scrutiny. And because the Court recognizes that the right to free speech lies at the cornerstone of the American liberal experiment, opponents of the Feinstein regulation believe they can rest comfortably knowing that any content-based prohibition of speech aimed at bomb-making instructions will not likely prevail. Yet one thing is clear, now that the Feinstein Amendment has become law: the first time a person is charged with a crime under this statute, the debate will become even more animated. And such a debate may more clearly come into focus if one examines the Court's long history of prioritizing certain forms of speech.

Some will no doubt remain unpersuaded by my claim that messages describing designs for pipe bombs belong within the category of scientific speech. Justice Jackson, after all, is famous for noting that the Constitution is not "a suicide pact." In fact, it may be good policy to suppress speech directed towards violence because such speech does indeed result in destruction. But policy is often incompatible with the Constitution. As Cass Sunstein $(1993,134)$ has written, "Government is rightly distrusted when it is regulating speech that might harm its own interests" (Strauss 1991; Zer-Ilan 1997). Insofar as pipe bombs are bombs, then from a judicial perspective they belong inside the same category as more sophisticated weaponry. And insofar as those more sophisticated weapons have contributed, and will continue to contribute, to scientific development more broadly, speech that describes these instruments falls under the protective watch of the First Amendment. In the end, we must always remember that speech is distinct from action, that one's words about bombs are not equivalent to the bombs themselves. It is a lesson the judiciary regularly acknowledges is essential if the principle of free speech is to remain in its elevated position. Legislatures around the country are right to criminalize the act of terrorism. But terrorism 
is separable from literature exploring all aspects of the phenomenon, including descriptions of the tools of the terrorist's trade. Indeed, we set foot atop a slippery slope if we confuse the act of destruction with the words that give rise to its possibility.

\section{NOTES}

${ }^{1}$ Terminiello v. City of Chicago, 337 U.S. 1, at 37 (1949) (Jackson, J., dissenting).

${ }^{2}$ Law enforcement officials argue that the increase in terrorism in recent years is partially attributable to the availability of violent material on the Internet. See Rose Aguilar and Jim Davis. "Terrorism Fight Spreads to Net," CNET News.com, July 31, 1996.

${ }^{3}$ Replacing printed materials related to bombmaking, such as: Guerilla's Arsenal: Advanced Techniques for Making Explosives and Time-delay Bombs (Paladin Press 1994); The Anarchist Arsenal (Harber Books, 1992); The Anarchist Handbook (J. Flores 1995); and Improvised Explosives: How to Make Your Own (Paladin Press 1985).

${ }^{4}$ Department of Justice. "1997 Report on the Availability of Bomb-making Information." The Report went on to note that "bomb-making information is literally at the fingertips of anyone with access to a home computer equipped with a modem." A simple scan of available information revealed that many websites not only identify the necessary ingredients of "cherry bombs," "calcium carbide bombs," "jug bombs," fertilizer bombs, and other explosive devices, but also suggest ways to use them after fabrication. In addition, a Department of Justice review of available information revealed that a significant number of people utilize "Usenet" newsgroups to "facilitate the exchange of information concerning the fabrication and use of explosives and other dangerous weapons."

${ }^{5}$ The bill is sponsored by Orrin Hatch (R-UT), and it is part of an ongoing attempt by the Senate to reconfigure the laws governing juvenile justice in this country.

${ }^{6}$ The Hatch legislation is not as concerned with the issue of intent. The clause relating to the prohibition of bombmaking information makes clear that the speaker will be punished if she "knowingly transmits" designs for bombs or other explosives. What it doesn't include, however, is the section of the Feinstein Amendment that requires criminal action.

${ }^{7} \mathrm{My}$ argument must acknowledge the possibility that these legislative restrictions may satisfy the judiciary's two-part test for strict scrutiny: that the legislation serve a compelling state objective and that the means to achieve that objective be closely tailored. Yet if history is any barometer, very few pieces of legislation have satisfied strict scrutiny.

${ }^{8}$ Justice Stevens has been the strongest advocate of sexually explicit utterances being viewed as lower valued speech. See Young v. American Mini Theatres, 427 U.S. 50 (1976). In fact, the entire judiciary has upheld many restrictions on sexually explicit speech not defined as obscene. For example, the Court has upheld zoning regulations on pornographic speech in Young v. American Mini Theatres, 427 U.S. 50 (1976), held that the FCC has the authority to regulate indecent broadcasts (see FCC v. Pacifica Foundation, 438 U.S. 726 (1978)), and determined that the negative "secondary effects" that result from pornographic and similarly explicit messages warrant governmental regulation (see Renton v. Playtime Theatres, Inc., 475 U.S. 41 (1986)). In the end, it is clear that pornography, and other sexually explicit materials may be regulated to some degree. As such, speech that appeals to the sexual impulses of individuals - speech that is in fact one 
step removed from the obscene-must be recognized as occupying the lowest rung on the hierarchy of protected expression.

${ }^{9}$ Moreover, in Dow Chemical Co.v. Allen (1982), the Seventh Circuit asserted that "whatever constitutional protection is afforded by the First Amendment extends as readily to the scholar in the laboratory as to the teacher in the classroom." See Dow Chemical Co.v. Allen, 7th Cir., 672 F.2d 1262, 1275 (1982).

${ }^{10}$ The closest relative to the pipe bomb, in fact, is the grenade and the landmine, both of which have helped further other scientific advancements as well as military progress.

${ }^{11}$ The Federation of American Scientists, a non-profit organization founded in 1945 by members of the Manhattan Project, is an example of an organization devoted to using the technology developed in the nuclear age to help improve lives around the world. The group is made up of scientists (including over half of America's living Nobel Laureates) who are engaged in a number of projects relating to energy conservation, agricultural improvements, medical care, etc. Presumably their work would be stifled by legislation that regulates/prohibits the knowing transmission of designs that could lead to the construction of explosives or other violent materials.

${ }^{12}$ Saunders insists that the history outlawing violent speech mirrors the history outlawing graphic sexual speech until the Court's 1957 decision in United States v. Roth, 354 U.S. 476. After that, the judiciary's treatment of both subjects differed significantly.

${ }^{13}$ One need only review the Court's Clear and Present Danger cases from Schenck v. United States, 249 U.S. 47 (1919), to Brandenburg v. Ohio, 395 U.S. 444 (1969) to conclude that the mere potential of violence alone is no longer sufficient to warrant the suppression of speech.

${ }^{14}$ Consider Brandenburg v. Ohio, 395 U.S. 444 (1969), as well as the line of cases that preceded it, in which the Court refused to allow the Government to silence speakers in their various attempts to incite violence.

${ }^{15}$ See Papish v. Board of Curators of the University of Missouri et al., 410 U.S. 667 (1973); Hustler Magazine v. Falwell, 485 U.S. 46 (1988).

${ }^{16}$ In addition, it also seems appropriate to point out that the distance between obscenity and pornography on the constitutional hierarchy is minimal (separated only by the thin line demarcating protected speech from unprotected speech), but that to draw a distinction between good science and bad science would result in a separation of tremendous distance.

\section{REFERENCES}

Aguilar, Rose, and Jim Davis. 1996. Terrorism Fight Spreads to Net. CNET News.com, July.

American Booksellers Assn. v. Hudnut. 1985. 7th Cir., 771 F.2d 323.

Amsterdam, Anthony. 1960. The Void-for-Vagueness Doctrine in the Supreme Court. University of Pennsylvania Law Review 109:67-116.

Bantam Books, Inc. v. Sullivan. 1963. 372 U.S. 58.

Bernard, Chris G. 1999. The Child Online Protection Act: Can the COPA Cope with Constitutional Scrutiny in Light of Reno v. ACLU? Wayne Law Review 45:16651691.

Brandenburg v. Ohio. 1969. 395 U.S. 444.

Carey v. Populations Services International. 1977. 431 U.S. 678. 
Chaplinksy v. New Hampshire. 1942. 315 U.S. 568.

Cole, April Bailey. 1999. Indecency on the Internet: Reno and the Communications Decency Act of 1996. Capital University Law Review 27:607-638.

Cox, David T. 1999. Litigating Child Pornography and Obscenity Cases in the Internet Age. Journal of Technology Law and Policy 4:1-149.

Doherty, Kelly. 1999. www.obscenity.com: An Analysis of Obscenity and Indecency Regulation on the Internet. Akron Law Review 32:259-300.

Dow Chemical Co. v. Allen. 1982. 7th Cir., 672 F.2d 1262.

Dun \& Bradstreet v. Greenmoss Builders, Inc.1985. 472 U.S. 749.

Emerson, Thomas. 1970. The System of Freedom of Expression. New York: Vintage Books.

Fallon, Richard H. 1991. Making Sense of Overbreadth. Yale Law Journal 100:853-908.

FCC v. Pacifica Foundation. 1978. 438 U.S. 726.

Federalist 78. New York: Modern Library

Harber, David. 1994. Guerilla's Arsenal: Advanced Techniques for Making Explosives and Time-delay Bombs The Anarchist Arsenal. Boulder, CO: Paladin Press.

Hurley v. Irish-American Gay, Lesbian \& Bisexual Group. 1995. 115 S. Ct. 2338.

Hustler Magazine v. Falwell. 1988. 485 U.S. 46

Konigsberg v. State Bar of California. 1961. 366 U.S. 36.

Lecker, Seymour. 1985. Improvised Explosives: How to Make Your Own. Boulder, CO: Paladin Press.

Marts, Gary D. 2003. It's OK-She's a Pixel, Not a Pixie: The First Amendment Protects Virtual Child Pornography. Arkansas Law Review 25:717-752.

Meiklejohn, Alexander. 1948. Free Speech and Its Relation to Self Government. New York: Harper.

Miller v. California. 1973. 413 U.S. 15

Miller, Heather L. 1999. Strike Two: An Analysis of the Child Online Protection Act's Constitutional Failures. Federal Communications Law Journal 52:155-188.

NAACP v. Claiborne Hardware Co. 1982. 458 U.S. 886 at 913

New York Times Co. v. Sullivan. 1964. 376 U.S. 254.

Note. 1969. The Chilling Effect in Constitutional Law. Columbia Law Review 69:808842.

Noto v. United States. 1961. 367 U.S. 290.

Ota, Alan K. 1999. Regulating the Internet: Congress Asserts Domain. CQ Weekly 57:3435, September.

Papish v. Board of Curators of the University of Missouri et al. 1973. 410 U.S. 667

Phillips, Scott, and Ryken Grattet. 2000. Judicial Rhetoric, Meaning-Making, and the Institutionalization of Hate Crime Law. Law and Society Review 34:567-606.

Progressive v. United States. 1979. 467 F. Supp. 990 (W.D. Wis.).

Redish, Martin H. 1983. The Warren Court, the Burger Court, and the First Amendment Overbreadth Doctrine. Northwestern Law Review 78:1031-1070.

Reno v. American Civil Liberties Union. 1997. 521 U.S. 844.

Renton v. Playtime Theatres, Inc.1986. 475 U.S. 41.

Ross, Catherine. 2000. Anything Goes: Examining the States Interest in Protecting Children from Controversial Speech. Vanderbilt Law Review 53:427-524.

Sargentich, Lewis. 1970. The First Amendment Overbreadth Doctrine. Harvard Law Review 83:844-927.

Sable Communications of California, Inc. v. FCC. 1989. 492 U.S. 115

Saunders, Kevin W. 1996. Violence as Obscenity: Limiting the Media's First Amendment Protection. Durham, NC: Duke University Press. 
Schauer, Frederick. 1981. Categories and the First Amendment. Vanderbilt Law Review 34:265-307.

Schenck v. United States. 1919. 249 U.S. 47.

Seigel, Michael L. 1999. Hate Speech, Civil Rights and the Internet: The Jurisdictional and Human Rights Nightmare. Albany Law Journal of Science and Technology 9:375-398.

Strauss, David. 1991. Persuasion, Autonomy, and Freedom of Expression. Columbia Law Review 91:334-371.

Sunstein, Cass R. 1993. Democracy and the Problem of Free Speech. New York: Free Press.

Sweezy v. New Hampshire. 1957. 354 U.S. 234, 261-262.

Terminiello v. City of Chicago. 1949. 337 U.S. 1.

Tsesis, Alexander. 2000. The Empirical Shortcomings of First Amendment Jurisprudence: A Historical Perspective on the Power of Hate Speech. Santa Clara Law Review 40:729-786.

U.S. Department of Justice. 1997. Report on the Availability of Bomb-making Information. Washington, DC: Department of Justice.

United States v. Roth. 1957. 354 U.S. 476.

Virginia State Bd. of Pharmacy v. Virginia Citizens Consumer Council. 1976. 425 U.S.

Wells, Robert. 1985. The Anarchist Handbook. Miami, FL: J. Flores Publications.

Witte, Gretchen. 1999. Internet Indecency and Impressionable Minds. Villanova Law Review 44:745-780.

Winters v. New York. 1948. 333 U.S. 507.

Young v. American Mini Theatres. 1976. 427 U.S. 50.

Zer-Ilan, Avital T. 1997. The First Amendment and Murder Manuals: Rice v. Paladin Enterprises, Inc. Yale Law Journal 106:2697-2702. 
